
NASKAH DALAM KAJIAN ANTARDISIPLIN

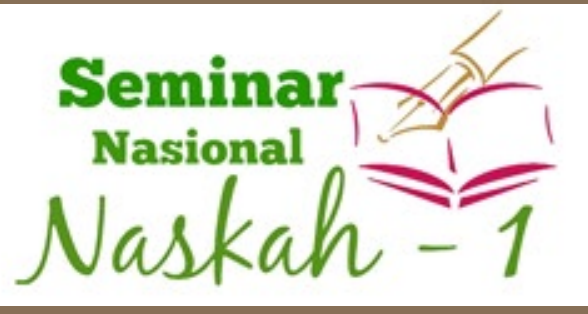

Fakultas IImu Pengetahuan Budaya Universitas Indonesia 2019

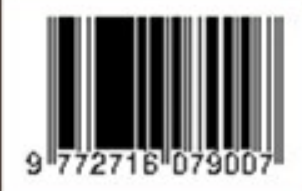

Didukung oleh :

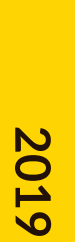
2) $\stackrel{ }{\stackrel{0}{\ominus}}$ (D) Badasa Pengermbangan

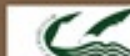

\section{(1)|}

Fakultas IImu Pengetahuan Budaya Universitas Indonesia 


\section{Prosiding}

ISSN 2716-0793

\section{Seminar Nasional \\ Naskah dalam Kajian Antardisplin}

Fakultas IImu Pengetahuan Budaya

Universitas Indonesia

2019 


\section{Prosiding Seminar Nasional Naskah dalam Kajian Antardisplin}

Hak cipta dilindungi undang-undang

Copyright@2019

ISSN: 2716-0793

PENYUNTING

Priscila F. Limbong

Munawar Holil

Mamlahatun Buduroh

TATA LETAK \& SAMPUL

Wina A. Tirtapradja

\section{PENYELENGGARA}

Laboratorium Filologi

Departemen Ilmu Susastra

FIB UI

Bekerjasama dengan

Masyarakat Pernaskahan Nusantara,

Pusat Penelitian Kemasyarakatan dan Budaya

FIB UI,

Badan Pengembangan Bahasa dan Perbukuan

Kementrian Pendidikan dan Kebudayaan, dan

Perpustakaan Nasional

Republik Indonesia 


\section{KATA PEMBUKA}

Assalamu'alaikum warahmatullahi wabarakatuh.

Yang terhormat

1. Prof. Dr. Achadiati Ikram

Dewan Penyantun Manassa

2. Dr. Munawar Holil, M.Hum.

Ketua Umum Manassa sekaligus Kepala Laboratorium Filologi FIB UI

3. Dr. Ali Akbar, M.Hum.

Kepala PPKB UI

4. Prof. Dr. Gufron Ali Ibrahim, M.S.

Kepala Pusat Pengembangan dan Pelindungan

Bahasa dan Sastra Badan Pengembangan Bahasa dan Perbukuan

5. Drs. Teguh Purwanto, S.IP., M.Hum.

Kepala Pusat Jasa Perpustakaan dan Informasi

Perpustakaan Nasional Republik Indonesia

Yang diwakili IbuYeri Nurita, S.S. (Kepala Bidang Layanan Koleksi Khusus)

6. Dr. Adrianus L.G. Waworuntu, S.S., M.Hum.

Dekan FIB UI

Yang diwakili Ibu Nurni Wahyu Wuryandari, Ph.D. (Manager Pendidikan)

7. Dr. Dhita Hapsarani, M.Hum.

Ketua Departeman Ilmu Susastra FIB UI

8. Para Narasumber, Pemakalah

9. Panitia, dan

10. Para hadirin yang saya cintai

Puji syukur saya panjatkan ke hadirat Allah Yang Maha Esa karena atas limpahan rahmat-Nya serta kasih sayang-Nya kita semua bias berkumpul Bersama untuk menghadiri acara Seminar Nasional Naskah Dalam Kajian Antardisiplin Pada Era 4.0 dalam keadaan sehat dan sejahtera.

Bapak, Ibu yang berbahagia,

Acara seminar ini dapat terselenggara atas kerjasama Laboratorium Filologi Departemen Ilmu Susastra FIB UI, PPKB FIB UI, Badan Pengembangan Bahasa dan Perbukuan, Serta Perpustakaan Nasional Republik Indonesia. Oleh karena itu, saya mengucapkan terima kasih kepada Bapak Dr. Munawar Holil, Bapak Dr. Ali Akbar, Bapak Prof. Dr. Gufron Ali Ibrahim, dan Bapak Drs. Teguh Purwanto, M.Si atas fasilitas dan dukunganya pada acara seminar ini. Saya juga mengucapkan terima kasih kepada para narasumber dan pemakalah yang bersedia berbagi pengetahuan terkait kajian naskah. Untuk kesedian Bapak, Ibu, dan para hadirin yang meluangkan waktu untuk acara ini, saya mengucapkan banyak terima kasih. Tidak lupa saya mengucapkan terima kasih yang sebesar-besarnya kepada seluruh panitia acara yang telah membantu mencurahkan pemikiran dan tenaganya mulai awal hingga acara ini terlaksana dengan baik. Semoga Allah membalas kebaikan Bapak dan Ibu dengan kesejahteraan di dunia dan di akhirat. 
Para hadirin yang saya hormati,

Sebagai informasi, acara ini bertujuan untuk menyebarluaskan pengetahuan dan temuan-temuan terbaru terkait kajian naskah klasik antardisiplin pada era 4.0. Selain itu, pada acara ini akan diluncurkan buku karya mahaguru filologi, Prof. Dr. Achadiati Ikram, yang berjudul Pengantar Penelitian Filologi, penampilan tari tradisional, demo menulis di atas lontar, dan workshop daluwang. Terkait dengan acara seminar, sebagai laporan, pemakalah yang berpartisipasi pada acara ini berjumlah 51 orang dengan jumlah makalah yang dipresentasikan sejumlah 33 makalah. Adapun jumlah peserta seminar ini sejumlah 169 orang yang berasal dari berbagai kalangan dan wilayah.

Hadirin yang berbahagia, saya menyadari bahwa penyelenggaran seminar ini masih banyak kekurangan baik dalam penyajian acara, pelayanan administrasi maupun keterbatasan fasilitas. Untuk itu kami mohon maaf yang sebesar-besarnya. Akhir kata semoga seminar ini dapat menambah pengetahuan, wawasan, dan pemahaman kita dalam bidang naskah klasik.

Depok, 5 November 2019

Dr. Priscila Fitriasih Limbong, S.S., M.Hum.

Ketua Panitia 


\section{DAFTAR ISI}

Kata Pembuka $\quad$ iii

Daftar Isi $\quad$ V

\section{Pembicara Utama}

MU'JIZAH

Naskah sebagai Sumber Kajian Interdisipliner $\quad 1$

SUDIBYO

Menegosiasikan Kembali Filologi dalam Ranah Ilmu-Ilmu Humaniora 18

TITIK PUDJIASTUTI

Penelitian Naskah Kalimantan Timur dan Utara di Era 4.0 30

Pemakalah

ABIMARDHA KURNIAWAN

Ketika Angka Bertemu Bulatan-bulatan: Sebuah Ikhtiar Menafsirkan Sěngkalan 44

Dihyang

ABDULLAH MAULANI

Buk sebagai Material Culture dan Simbol Perlawanan atas Kolonialisme di 58

Kabupaten Indramayu, Jawa Barat Abad XIX

AGUS ISWANTO, UMI MASFIAH, \&MOCH LUKLUIL MAKNUN

Naskah Keislaman di Klungkung dan Karangasem Bali: Sebuah Penelusuran Awal

66

terhadap Koleksi Masyarakat

AHMAD ALFAN RIZKA ALHAMAMI

Arjunawiwaha: Alih Wahana Teks Kakawin Menjadi Naskah Pakem Pewayangan

78

DEDE HIDAYATULLAH

Naskah dan Kajian Sastra Lisan di Kalimantan Selatan 102

DIYAH PRILLY UPARTINI

Formula Glorifikasi Pemimpin dalam Hikayat Banjar

DEWAKI KRAMADIBRATA

Bahasa Melayu dalam Dua Teks Hikayat Muhammad Hanafiyah

EKA SUCI SETYANINGRUM \& TITIK PUDJIASTUTI

Sejarah Tradisional Jawa dalam Jawata Jawa Dipa 
IWAN GUNAWAN, AREISPINE DYMUSSAGA S. MIRAVIORI, \& ARKAN TANRIWA

Pelajaran Menjadi Hindia Belanda: Pembentukan Karakter melalui Buku Sekolah

MOHAMAD WAHYU HIDAYAT

Perbandingan Citra Tokoh Utama dalam Satwa Pan Balang Tamak dan Hikayat Abu

Nawas

MUHAMMAD BILAL RADHITYA PRAHASYA \& NANNY SRI LESTARI

Menelusuri Karakteristik Permainan Tradisional dan Fenomena Game Online di Era

Digital

MURNI WIDYASTUTI

Legenda Setempat Koleksi Naskah-Naskah Karangan Jayengwiharja

NAUFAL ANGGITO YUDHISTIRA, TANIA DWI RAHMA, \&TURITA INDAH SETYANI

Sinkretisme Agama dalam Kidung Surajaya: Representasi Kehidupan Beragama pada Skriptorium Merapi-Merbabu

NAUFAL ANGGITO YUDHISTIRA \& I MADE SUPARTA

Simbol Pengruwatan dalam Rajah pada Naskah Panangkis Sarwa Mawiçeșa

NOVARINA

Serat Petimah Sami dan Hikayat Nabi Muhammad dalam Perbandingan Tema dan

Motif Cerita

NOVIANA DEWI SHINTA \& NANNY SRI LESTARI

Makna dan Pesan Kemakmuran Di Balik Kata Sindhureja

NYIMAS UMI KALSUM

Konsep Akidah dalam Naskah Aqidatu -l Awam

PRISCILA FITRIASIH LIMBONG

Relasi Kuasa yang Terdapat pada Metafora Arsip-Arsip Sultan Ternate

PUTRI NUR SARASWATI \& JULIA WULANDARI

Reduplikasi dari Waktu ke Waktu Studi Kasus: Naskah Kuno Melayu

RAHMATIA AYU WIDYANINGRUM

Naga dalam Alam Pikiran Bugis-Makassar Berdasarkan Naga Sikoi

RATNA DJUMALA

Membangun Karakter Anak Lewat Permainan Tradisional: Sebuah Tinjauan

Pendahuluan pada Naskah Jongensspelen dan Meijesspelen 
RIAS A. SUHARJO

Eksordium Hikayat Sultan Taburat: Tentang Naskah, Teks, dan Sarana Berbagi Rasa

ROHIM

Model Epos dalam Syair Baginda Hamzah (SBH)

304

SINTA RIDWAN

Menelisik Latar Kemunculan Aksara di Jawa Bagian Barat: Sebuah Upaya

Pembacaan Awal

SITI HOTIJAH \& DEWAKI KRAMADIBRATA

Surat Kontrak Tidore

SYAHRIAL

Digitalisasi Naskah sebagai Upaya Pelestarian: Beberapa Catatan Singkat

UTE LIES SITI KHADIJAH, LUTFI KHOERUNNISA, EDWIN RIZAL, EVI NOVIANTI, \&IPIT ZULFAN

Kebijakan Pengelola Perpustakaan Yayasan Pangeran Sumedang dalam Menjaga

Naskah Kuno

ZULFA OKTAFIANI \& NANNY SRI LESTARI

Tema dan Pesan Cerita Sri Tanjung yang Tersirat dalam Teks Ratu Sepuhing

Sindhureja

Kata Penutup

375 


\title{
NASKAH KEISLAMAN DI KLUNGKUNG DAN KARANGASEM BALI: SEBUAH PENELUSURAN AWAL TERHADAP KOLEKSI MASYARAKAT
}

\author{
Agus Iswanto \\ Umi Masfiah \\ Moch Lukluil Maknun \\ Badan Penelitian dan Pengembangan dan Pendidikan dan Pelatihan-Kementerian Agama \\ agus.iswanto83@gmail.com \\ masfiah.umi@gmail.com \\ lukluilmaknun84@gmail.com
}

\begin{abstract}
Abstrak
Naskah-naskah keislaman di Bali belum banyak diungkapkan, baik dalam bentuk deskripsi maupun dalam kajian-kajian yang spesifik, padahal banyak masyarakat Muslim di kampungkampung Islam Bali menyimpan naskah keislaman. Artikel ini menyajikan hasil penelusuran naskah-naskah keislaman koleksi masyarakat di dua kabupaten di Bali, yakni Kabupaten Klungkung dan Kabupaten Karangasem. Artikel ini bermula dengan menyajikan kampungkampung Islam dan para pemlilik naskah, lalu dilanjutkan dengan penyajian hasil identifikasi naskah yang ditemukan. Identifikasi tersebut meliputi identifikasi alas/bahan naskah, bahasa dan aksara, serta isi teks. Artikel ini juga mengidentifikasi naskah-naskah keislaman yang memiliki kolofon. Naskah-naskah keislaman yang berhasil ditemukan lebih banyak ditemukan di Kabupaten Karangasem, sementara di Kabupaten Klungkung hanya sedikit naskah yang ditemukan. Kebanyakan naskah berbahan kertas Eropa, meskipun ada juga naskah yang berbahan dluwang, kertas bergaris, dan lontar. Dari segi bahasa, naskah-naskah keislaman yang berhasil diidentifikasi banyak menggunakan bahasa Melayu dan aksara Jawi, tetapi ada juga yang menggunakan bahasa Jawa dan Bali. Naskah-naskah tersebut berisi berbagai keilmuan Islam, seperti tauhid, fikih dan tasawuf, tetapi yang banyak ditemukan adalah naskah-naskah cerita/hikayat, khutbah, dan primbon.
\end{abstract}

Kata kunci: Naskah keislaman, Islam di Bali, kodikologi, filologi

\section{Pendahuluan}

Khazanah naskah-naskah keislaman di Bali-sebagaimana yang disebut oleh Pigeaud (1967: 102) — belum banyak diungkapkan, baik dalam bentuk deskripsi, maupun dalam kajiankajian yang lebih spesifik. Padahal, sesungguhnya pernyataan Pigeaud yang mengaitkan naskah keislaman di Bali dengan komunitas Muslim yang ada di pulau ini menjadi penanda penting bagi perkembangan dan sejarah Islam di pulau ini, selain juga sebagai identitas yang dibangun, serta relasi antar budaya keagamaan yang diartikulasikan dalam naskah-naskah tersebut.

Berbeda dengan khazanah naskah-naskah Bali bercorak Hindu yang relatif sudah banyak diketahui, masih diperlihara, bahkan masih "hidup" tradisi penyalinannya hingga kini, naskahnaskah keislaman di Bali belum banyak diketahui, dilestarikan, atau dikaji, apalagi daftar atau katalog yang mendeskripsikan naskah-naskah keislaman di Bali juga belum tersedia. Hal tersebut dikarenakan kebanyakan naskah-naskah keislaman di Bali masih disimpan oleh masyarakat di beberapa kampung Islam, sehingga akses untuk mendapatkan informasi keberadaan naskah tersebut susah. Selain itu, khazanah naskah Bali bercorak Hindu, yang lebih dikenal ditulis dalam lontar, lebih populer di kalangan umat Hindu yang memang menjadi umat beragama terbanyak di Pulau Bali. Bahkan, beberapa lembaga pemerintah dan keagamaan Bali secara khusus menyimpan koleksi naskah lontar Hindu ini. 
Menurut catatan Chambert-Loir dan Fathurahman (1999: 52-64) naskah-naskah Bali tersimpan di beberapa lembaga. Namun, lebih banyak lagi koleksi naskah Bali milik perseorangan atau masyarakat. Naskah-naskah keislaman di Bali banyak tersimpan di masyarakat. Naskah-naskah keislaman di Bali adalah bagian dari khazanah masyarakat Muslim Bali yang belum diinventarisasi secara sistematis, apalagi dikaji sebaik mungkin untuk memahami corak keislaman dan perkembangannya hingga sekarang. Naskah-naskah tersebut juga dapat menjadi bukti kebaradaan komunitas Muslim Bali, tradisi keagamaan dan keilmuan Islam yang dipraktikan dan diajarkan. Naskah-naskah tersebut juga dapat menjadi bukti tentang relasi komunitas Muslim Bali dengan komunitas Muslim di luar pulau Bali. Oleh karena itu, inventarisasi naskah-naskah keislaman di kalangan masyarakat Muslim Bali penting dilakukan.

Tulisan ini melaporkan hasil penelusuran naskah keislaman di dua wilayah Provinsi Bali, yakni Kabupaten Klungkung dan Karangasem. Dua Kabupaten ini memiliki banyak kampung Islam. Tidak semua deskripsi naskah ditampilkan dalam tulisan ini, tetapi hanya menampilkan beberapa temuan penting dari inventarisasi tersebut, sementara seluruh deskripsi naskah akan disampaikan dalam katalog yang akan disusun. Tidak juga semua kampung yang ada di dua kabupaten tersebut berhasil ditemukan koleksi naskahnya, tetapi ini cukup dapat membuktikan pernyataan Pigeaud tentang keberadaan naskah-naskah keislaman di kampung-kampung Muslim di Bali, sekaligus melengkapi temuan Saefullah dan Islam (2010) yang telah lebih dahulu melakukan pemetaan terhadap naskah-naskah keislaman di Bali.

Hasil penelitian Saefullah dan Islam (2010) untuk Kabupaten Karangasem dan Klungkung hanya mencatat satu kampung Islam, yakni Kampung Buitan. Itupun hanya satu naskah. Akhirnya, secara snowball kami melakukan penelusuran. Beberapa narasumber kami wawancara untuk mendapatkan informasi tentang keberadaan naskah-naskah tersebut. Melalui metode snowball, ditemukan sejumlah pemilik di beberapa kampung Islam yang ada di Klungkung dan Karangasem.

Naskah-naskah tersebut selanjutnya dicatat, diberi kode, dan dideskripsikan sesuai instrumen yang tersedia. Setelah dideskripsikan, naskah selanjutnya dialihmediakan (digitalkan) dengan teknik fotografi. Inventarisasi dilakukan dengan mendeskripsikan isi teks dan kondisi fisik naskah, oleh karena itu, digunakan dua metode sekaligus, yakni metode filologi (Fathurahman, 2016: 66), dan metode kodikologi (Mulyadi, 1994: 1; Pudjiastuti, 2006: 10). Beberapa aspek naskah yang dilihat secara kodikologis dalam penelitian ini adalah alas naskah/bahan naskah, tinta, ukuran naskah, ukuran teks, jumlah halaman, jumlah baris per halaman, jenis sampul, teknik penjilidan, jumlah kuras, cap air/cap kertas (watermark), dan kolofon naskah.

\section{Kampung-kampung Islam di Karangasem dan Klungkung}

Kampung-kampung Islam di Karangasem dan Klungkung Bali penting dijelaskan. Hal itu karena kampung-kampung tersebut menjadi tempat disimpannya naskah-naskah keislaman di Karangasem dan Klungkung. Ada tujuh kampung Islam yang berhasil ditemukan memiliki naskah. Lima di Kabupaten Karangasem, dan dua di Kabupaten Klungkung. Masing-masing kampung rata-rata ditemukan satu pemilik naskah, hanya satu kampung yang ditemukan dua pemilik naskah. Kampung yang terbanyak ditemukan naskah adalah Kampung Saren Jawa di Kabupaten Karangasem.

Tabel 1

Kampung-kampung Islam di Klungkung yang Ditemukan Naskah Keislaman

\begin{tabular}{|l|l|l|}
\hline No & $\begin{array}{l}\text { Daftar Kampung-Kampung Islam di } \\
\text { Klungkung }\end{array}$ & $\begin{array}{l}\text { Kampung-kampung yang ditemukan Naskah } \\
\text { Keislaman }\end{array}$ \\
\hline 1 & Kampung Gelgel & Kampung Lebah \\
\hline 2 & Kampung Lebah & Kampung Kusamba \\
\hline 3 & Kampung Jawa & \\
\hline 4 & Kampung Kusamba & \\
\hline 5 & Kampung Toya Pakeh & \\
\hline
\end{tabular}


Adapun Kabupaten Karangasem memiliki sekitar 26 kampung Islam, yakni: Bukit Tabuan, Kampung Anyar, Karang Sasak, Tibulaka Sasak, Tihing Jangkrik, Karang Cermen, Nyuling, Ujung Pesisi, Ujung Sumbawa, Ujung Desa, Segara Katon, Dangin Sema, Bangras, Karang Langko, Karang Tohpati, Kampung Ampel, Karang Tebu, Jeruk Manis, Gelumpang Suci, Karang Sokong, Telaga Mas, Kecicang Islam, Kedokan, Saren Jawa, Sindu dan Buitan (Mashad, 2014: 170). Dari sekitar 26 kampung tersebut, kami baru mengunjungi delapan kampung, dan mendapatkan koleksi naskah di lima kampung. Melihat banyaknya kampungkampung Islam di Kabupaten Karangasem, masih dimungkinkan adanya naskah-naskah yang disimpan oleh masyarakat setempat. Sebetulnya kami menemukan satu naskah di Kampung Telaga Mas, tetapi menurut pemilik, atas wasiat orang yang menyerahkan kepadanya, naskah tersebut tidak perlu dipublikasi.

Tabel 2

Kampung Islam di Kabupaten Karangasem

\begin{tabular}{|l|l|l|l|}
\hline No & $\begin{array}{l}\text { Nama Kampung Islam di } \\
\text { Karangasem }\end{array}$ & $\begin{array}{l}\text { Kampung } \\
\text { Dikunjungi }\end{array}$ & $\begin{array}{l}\text { Kampung yang Ditemukan } \\
\text { Naskah }\end{array}$ \\
\hline 1 & Bukit Tabuan & Bukit Tabuan & Ujung Pesisi \\
\hline 2 & Kampung Anyar & Ujung Pesisi & Dangin Sema \\
\hline 3 & Karang Sasak & Dangin Sema & Kecicang Islam \\
\hline 4 & Tibulaka Sasak & Telaga Mas & Saren Jawa \\
\hline 5 & Tihing Jangkrik & Kecicang Islam & Sindu \\
\hline 6 & Karang Cermen & Saren Jawa & \\
\hline 7 & Nyuling & Sindu & \\
\hline 8 & Ujung Pesisi & Buitan & \\
\hline 9 & Ujung Sumbawa & & \\
\hline 10 & Ujung Desa & & \\
\hline 11 & Segara Katon & & \\
\hline 12 & Dangin Sema & & \\
\hline 13 & Bangras & & \\
\hline 14 & Karang Langko & & \\
\hline 15 & Karang Toh Pati & & \\
\hline 16 & Kampung Ampel & & \\
\hline 17 & Karang Tebu & & \\
\hline 18 & Jeruk Manis & & \\
\hline 19 & Gelumpang Suci & & \\
\hline 20 & Karang Sokong, Subagan & \\
\hline 21 & Telaga Mas & & \\
\hline 22 & Kecicang Islam & & \\
\hline 23 & Kedokan & & \\
\hline 24 & Saren Jawa & & \\
\hline 25 & Sindu & & \\
\hline 26 & Buitan & & \\
\hline
\end{tabular}

Dengan demikian, berikut beberapa pemilik naskah, lokasi, dan jumlah naskah yang didata dan digitalisasi dalam penelitian ini.

Tabel 3

Data Pemilik, Lokasi Kampung dan Jumlah Naskah

\begin{tabular}{|l|l|l|c|}
\hline No & Nama Pemilik & Lokasi & $\begin{array}{c}\text { Jumlah } \\
\text { Naskah }\end{array}$ \\
\hline 1 & H. Syamsul Hadiwijaya & Kampung Lebah, Klungkung & 1 \\
\hline 2 & Balai Desa Kampung Kusamba & Kampung Kusamba, Klungkung & 2 \\
\hline 3 & Bapak Jumaiyah & Ujung Pesisi, Karangasem & 1 \\
\hline 4 & Takmir Masjid Baiturrahman & Ujung Pesisi, Karangasem & 2 \\
\hline 5 & Haji Hasyim Ahmad & $\begin{array}{l}\text { Kampung Dangin Sema, } \\
\text { Karangasem Kecicang Islam, }\end{array}$ & 4 \\
\hline 6 & Haji Abdul Mahid (Almarhum) & $\begin{array}{l}\text { Kampung Karangasem Kecicang Islam, } \\
\text { Kamp }\end{array}$ \\
\hline 7 & Bapak Samidin & $\begin{array}{l}\text { Kampung Karangasem } \\
\text { Kan }\end{array}$ \\
\hline
\end{tabular}




\begin{tabular}{|l|l|l|c|}
\hline 8 & Takmir Masjid Baiturrahim & $\begin{array}{l}\text { Kampung Kecicang Islam, } \\
\text { Karangasem }\end{array}$ & 1 \\
\hline 9 & Haji Muhsan dan Bapak Nuruddin & Kampung Sindu, Karangasem & 4 \\
\hline 10 & Bapak Ayu Mudin & $\begin{array}{l}\text { Kampung Saren Jawa, } \\
\text { Karangasem }\end{array}$ & 41 \\
\hline 11 & Ibu Martilah & $\begin{array}{l}\text { Kampung Saren Jawa, } \\
\text { Karangasem }\end{array}$ & 17 \\
\hline \multicolumn{3}{|l|}{} & $\mathbf{7 5}$ \\
\hline
\end{tabular}

\section{Identifikasi Naskah Keislaman di Karangasem dan Klungkung}

Naskah-naskah keislaman di Klungkung dan Karangasem yang ditemukan kondisinya masih dapat dibaca, meskipun kebanyakan naskah-naskah sudah ada yang berlubang, terkikis bagian pinggir kertasnya, tidak lengkap atau ada yang kertasnya termakan tinta sehingga merusak tulisan. Namun, semua naskah-naskah keislaman yang berhasil diinventarisasi dalam tulisan ini adalah naskah-naskah yang masih dapat dibaca.

Informasi yang mendasar terkait pernaskahan keislaman di Klungkung dan Karangasem ini penting disampaikan. Hal ini dapat membantu para peneliti selanjutnya untuk mengakaji lebih jauh dan rinci mengenai isi dan sejarah naskah tersebut, dan hubungannya dengan sejarah dan identitas keislaman masyarakat Muslim di Bali, khususnya Klungkung dan Karangasem. Informasi tersebut biasanya beberapa identifikasi, baik dari segi fisik maupun teks yang terkandung di dalam naskah. Setidaknya ada tiga identifikasi yang bisa disampaikan dalam tulisan ini, yakni bahan/alas naskah, bahasa dan aksara, dan teks.

\section{Bahan/Alas Naskah}

Naskah-naskah keislaman di Klungkung dan Karangasem banyak menggunakan kertas Eropa sebagai bahan atau alas naskah, selain juga ada yang menggunakan kertas dluwang, kertas bergaris, bahkan lontar. Naskah yang menggunakan bahan kertas Eropa ditemukan sejumlah 31 naskah, yang menggunakan kertas dluwang 15 naskah, kertas bergaris 18 naskah, lontar lima naskah, kertas Cina tiga naskah, dan kertas foto copy 3 naskha. Memang sesuai apa yang dikatakan oleh Fathurahman (2016: 118), kertas Eropa adalah jenis kertas yang paling digunakan untuk naskah-naskah Nusantara, termasuk naskah-naskah keislaman. Kertas Eropa adalah kertas yang diimpor dari Eropa, umumnya mempunyai ciri, jika dilihat secara menerawang, ada baying-bayang garis acuan halus, baying garis acuan tebal, cap air/cap kertas (watermark), dan kadang-kadang disertai cap kertas bandingan (countermark) berupa nama atau inisial dari sipembuat atau penjual kertasnya (Pudjiastuti, 2006: 13).

Naskah-naskah yang berkertas Eropa tersebut telah coba peneliti identifikasi untuk memperkirakan angka tahun produksi dan penulisan/penyalinan teksnya. Tidak semua naskah yang menggunakan kertas Eropa dapat diidentifikasi dengan jelas. Hal itu disebabkan karena beberapa hal, bisa karena terlalu rapatnya tulisan atau teks sehingga menutupi gambar cap kertasnya, bisa juga karena cap kertas tidak ikut dalam bundel naskah yang diidentifikasi (Jones, 1974: 50). 


\section{Tabel 4}

Cap Kertas yang Berhasil Didapatkan Keterangannya

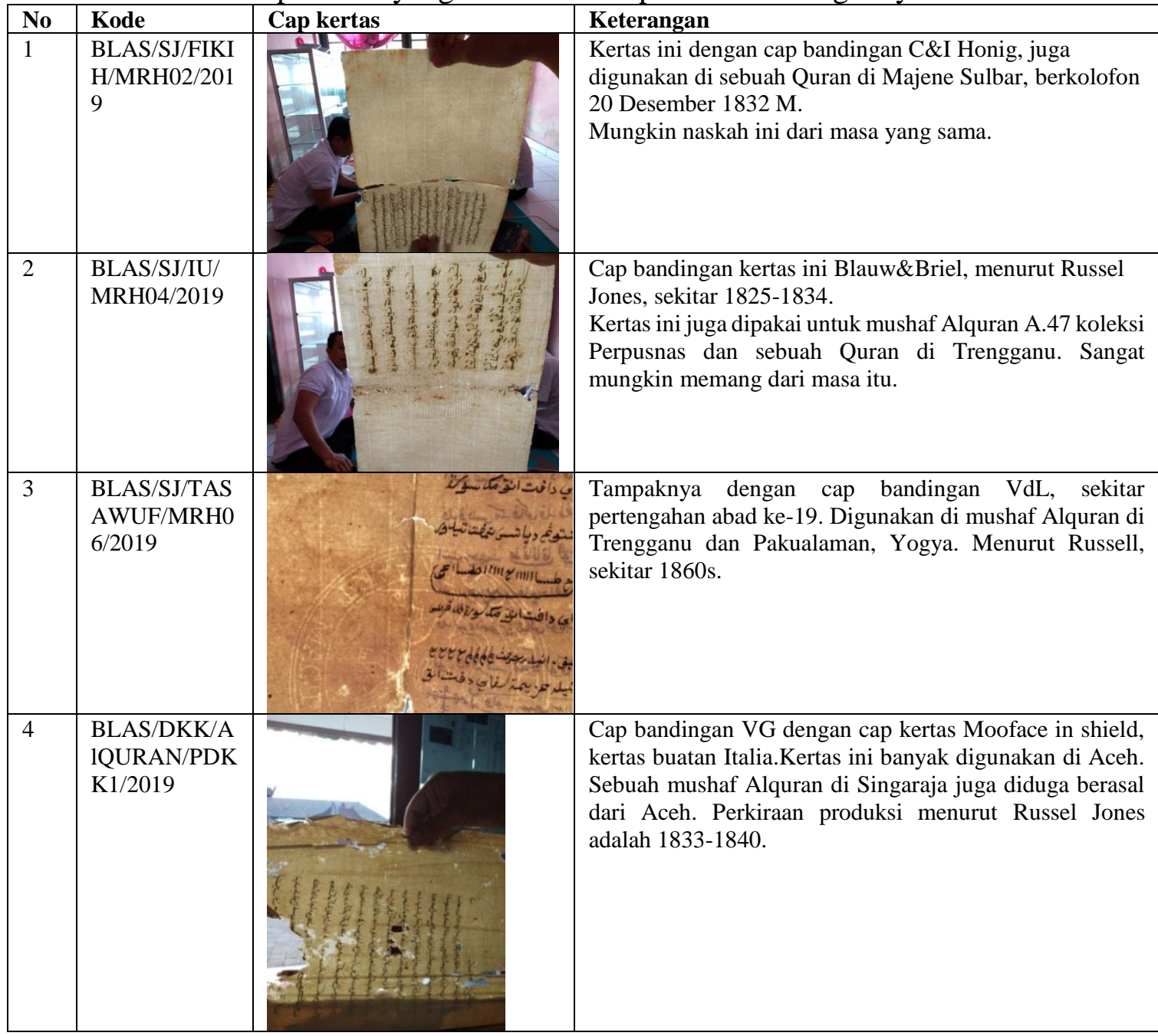

Tidak semua gambar cap kertas dapat ditemukan dalam naskah-naskah. Selain itu, identifikasi watermark memerlukan keahlian khusus dan kesabaran (Jones, 1974: 49) Karena itu, sulit pula untuk menentukan produksi dan waktu penyalinan naskahnya. Namun, secara umum, menurut Jones (1974: 49), kertas-kertas Eropa digunakan antara abad ke-17 hingga abad ke-19. Jadi bisa dimungkinkan, naskah-naskah yang menggunakan kertas Eropa disalin paling lambat di akhir abad ke-19. Jika kemungkinan ini tepat, maka naskah-naskah yang sampai hingga sekarang minimal berusia satu abad. 


\section{Gambar 1}

Naskah Hikayat Isra Mikraj dan Hikayat Nur Muhammad Disalin pada 2002 oleh Almarhum Abdul Mahid di Atas Kertas Bergaris

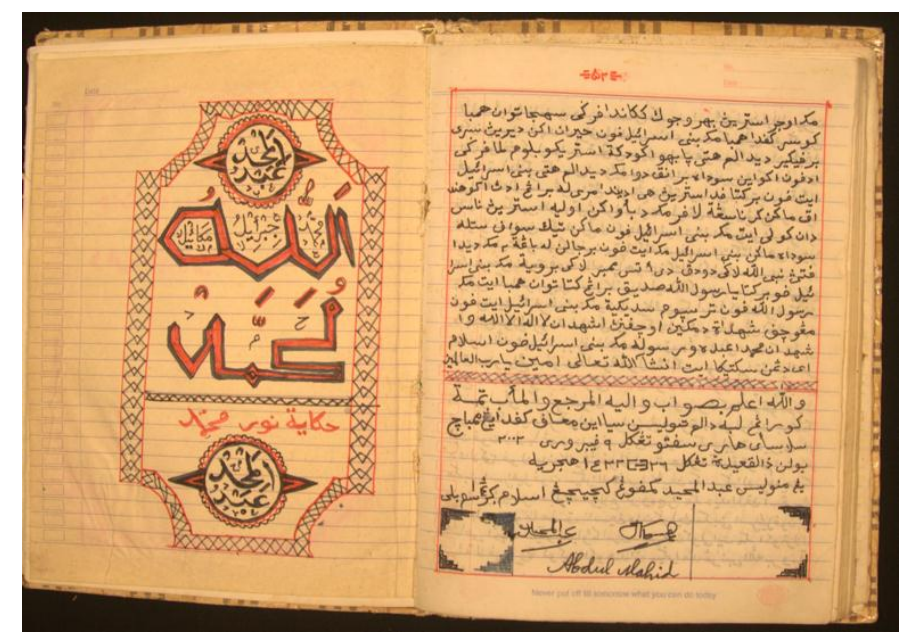

Sebuah teks yang dipandang penting akan senantiasa disalin lagi, begitu seterusnya. Karena itu ada juga naskah-naskah yang menggunakan kertas bergaris. Seiring dengan perkembangan teknologi, dengan muncul mesin foto copy, ada juga naskah-naskah tulisan tangan yang - karena beberapa alasan - diperbanyak dengan difoto copy, bukan lagi disalin sebagaimana dalam tradisi naskah yang ada. Teks-teks tersebut biasanya adalah teks-teks yang memang populer dan "hidup" dalam tradisi masyarakat, misalnya adalah teks hikayat Isra Mikraj (Suryadi, 2015). Dengan demikian, kertasnya pun adalah kertas modern folio ataupun A4 yang biasa digunakan dalam mesin foto copy.

\section{Bahasa dan Aksara}

Bahasa yang digunakan dalam naskah-naskah keislaman di Klungkung dan Karangasem bervariasi, mulai dari Jawa, Bali, Melayu, Jawa Kuno, hingga Belanda. Namun, yang terbanyak adalah bahasa Melayu. Setelah itu, diurutan kedua adalah bahasa Arab, lalu Jawa Kuno, gabungan Arab dan Melayu, gabungan Arab dan Jawa, Jawa, Bali, dan gabungan Jawa, Melayu dan Belanda. Bahasa Melayu justru menjadi bahasa terbanyak yang digunakan dalam naskahnaskah keislaman di Bali, di samping bahasa Arab yang memang jelas menjadi bahasa dalam tradisi keilmuan Islam. Pulau Bali yang letaknya dekat dengan pulau Jawa, justru bukan bahasa Jawa atau bahkan Bali sendiri yang banyak digunakan dalam naskah-naskah keislaman yang ditemukan, terutama di Kabupaten Karangasem. Ada juga yang sekaligus menggunakan dua atau tiga bahasa, seperti bahasa Melayu dan Arab, bahasa Arab dan Jawa, dan bahasa Jawa, Melayu, dan Belanda. Penggunaan dua bahasa ini biasanya adalah cara memberikan makna atas bahasa Arab yang juga digunakan, atau dalam satu naskah terdapat dua bahasa sekaligus. Berikut diagram yang menunjukkan jumlah bahasa-bahasa yang digunakan dalam naskahnaskah keislaman di Klungkung dan Karangasem. 


\section{Diagram 1}

Bahasa dalam Naskah-naskah Keislaman di Klungkung dan Karangasem

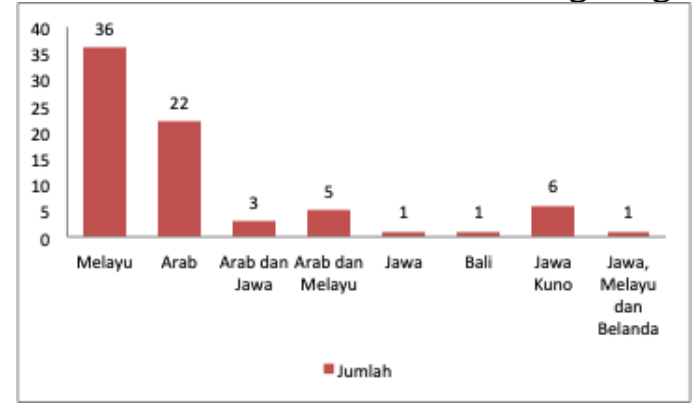

Adapun aksara yang terbanyak digunakan adalah aksara Jawi. Setelah itu aksara yang paling banyak kedua dalam naskah adalah aksara Arab, Bali, gabungan aksara Arab dan Jawi, Pegon (aksara Arab yang diadaptasi untuk bahasa Jawa), dan gabungan aksara Pegon, Jawi dan Latin. Naskah-naskah yang menggunakan gabungan aksara, baik Arab dan Jawi, Arab dan Pegon, maupun Pegon, Jawi dan Latin, ini dimaksudkan untuk memberikan pengertian atau penjelasan terhadap teks utama (matn), atau terjemahan antar baris (interlinear glose).

\section{Diagram 2}

Aksara dalam Naskah-naskah Keislaman di Klungkung dan Karangasem

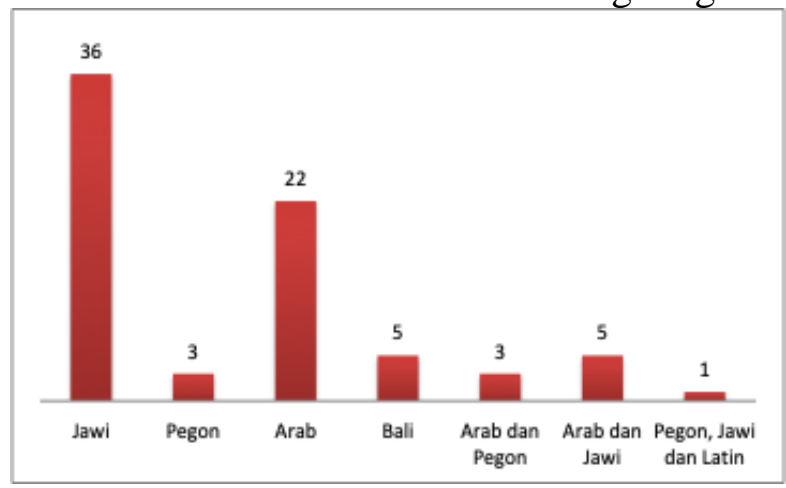

\section{Isi Teks}

Naskah-naskah keislaman di Klungkung dan Karangasem yang berhasil diinventarisasi terdiri dari berbagai macam teks keislaman. Kategorisasi ini dilakukan berdasarkan pada klasifikasi subjek keislaman yang disusun Kailani (1999). Berdasarkan klasifikasi tersebut, teks-teks keislaman yang terbanyak masuk ke dalam klasifikasi Islam Umum (IU). Penjabaran Islam Umum ini akan dilakukan di bawah. Setelah kategori Islam IU, teks yang terbanyak adalah tasawuf, lalu fikih, tauhid/ilmu kalam, Alquran dan bahasa. Ada naskah-naskah yang berisi lebih dari satu teks, tetapi kami menentukan teks yang terbanyak dalam naskah tersebut. Berikut ditampilkan kategori isi teks naskah-naskah keislaman secara umum. 


\section{Diagram 3}

Kategori Isi Teks Naskah-naskah Keislaman di Klungkung dan Karangasem

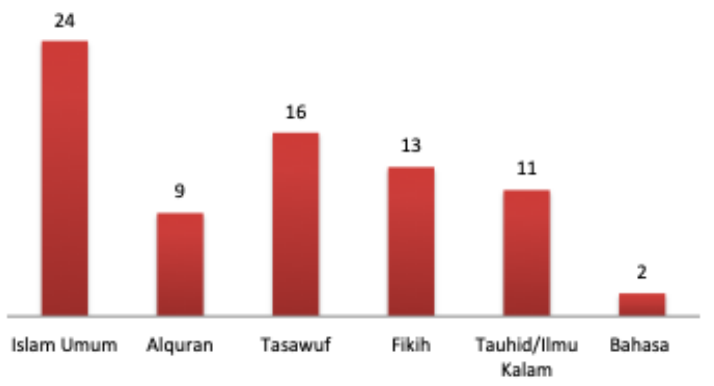

Sebagaimana sudah dikemukakan, bahwa isi teks yang terbanyak adalah kategori Islam Umum. Agar lebih mendapatkan gambaran apa saja yang termasuk kategori Islam Umum ini, kami perlu sampaikan rincian yang termasuk ke dalam kategori ini. Beberapa teks yang masuk ke dalam kategori Islam Umum ini adalah teks-teks hikayat atau cerita, baik dalam bentuk kertas maupun lontar; teks-teks khutbah; serta fragmen surat-surat. Ada juga tentang teks berisi perwatakan lahir dengan hiasan gambar yang indah, dan teks-teks azimat.

\section{Tabel 5}

Isi Teks Naskah-naskah Kategori Islam Umum

\begin{tabular}{|r|l|}
\hline \multicolumn{1}{|l|}{ No } & Isi Naskah \\
\hline 1 & Hikayat Isra Mikraj \\
\hline 2 & Hikayat Isra Mikraj \\
\hline 3 & Khutbah Min Yaumil Jumat \\
\hline 4 & Tembang Siti Fatimah \\
\hline 5 & Hikayat Isra Mikraj \\
\hline 6 & Lontar Semargame \\
\hline 7 & Lontar Monyeh \\
\hline 8 & Lontar Cerita Rengganis \\
\hline 9 & Lontar obat-obatan \\
\hline 10 & Lontar surat pemberian tanah \\
\hline 11 & Khutbah Jumat \\
\hline 12 & Khutbah Id \\
\hline 13 & Surat Wakaf \\
\hline 14 & Hikayat Isra Mikraj \\
\hline 15 & Khutbah Nikah \\
\hline 16 & Khutbah \\
\hline 17 & Azimat \\
\hline 18 & Perwatakan lahir \\
\hline 19 & Kitab Barzanzi \\
\hline 20 & Naskah khutbah \\
\hline 21 & Naskah Khutbah Jumat \\
\hline 22 & Kitab Azimat \\
\hline 23 & Khutbah Id \\
\hline 24 & Fragmen surat \\
\hline & \\
\hline
\end{tabular}




\section{Naskah-naskah Mushaf Alquran}

Naskah-naskah mushaf Alquran di beberapa tempat yang kami kunjungi tampaknya menjadi suatu "identitas" bagi pemiliknya. Selain itu, naskah-naskah mushaf tersebut dapat menjadi kajian tersendiri. Khazanahnaskah mushaf Alquran sudah dikaji oleh Zaelani dan Sudrajat (2015: 303-324), terutama tentang mushaf Alquran di Kampung Kusamba Klungkung, tetapi naskah-naskah mushaf Alquran lainnya di Karangasem belum dikaji. Oleh karena itu peneliti perlu sampaikan data naskah-naskah mushaf Alquran sebagai berikut.

\section{Tabel 6}

Naskah-naskah Mushaf Alquran di Klungkung dan Karangasem

\begin{tabular}{|c|c|c|c|c|c|c|}
\hline $\begin{array}{c}\text { Nama } \\
\text { Kampung }\end{array}$ & $\begin{array}{c}\text { Nama } \\
\text { Pemilik }\end{array}$ & Kolofon/Angka Tahun & Jenis Kertas & $\begin{array}{c}\text { Cap kertas/ } \\
\text { Cap } \\
\text { tandingan } \\
\end{array}$ & $\begin{array}{c}\text { Perkiraan } \\
\text { Waktu } \\
\text { Produksi } \\
\end{array}$ & Keterangan \\
\hline $\begin{array}{l}\text { Kecicang, } \\
\text { Karangasem }\end{array}$ & $\begin{array}{c}\text { Masjid } \\
\text { Baiturahman }\end{array}$ & $\begin{array}{c}\text { Khatam nulis Qur'an } \\
\text { dina Kamis tanggal } \\
\text { sepisan sasi mengaji } \\
\text { tahun ha Hijrah Nabi } \\
\text { Saw...1279 H /1800M }\end{array}$ & Kertas Eropa & Propatria & & $\begin{array}{l}\text { Alquran } \\
\text { lengkap }\end{array}$ \\
\hline $\begin{array}{l}\text { Kusamba, } \\
\text { Klungkung }\end{array}$ & $\begin{array}{l}\text { Balai Desa } \\
\text { Kampung } \\
\text { Kusamba }\end{array}$ & $\begin{array}{l}\text { Tamat kalimatu rabbika } \\
\text { sidqan wa mubadila } \\
\text { likalimati fi syahri } \\
\text { dulqa'dah almukaram } \\
\text { almubarak fi sanah ba } \\
\text { wazalika fil makan } \\
\text { alsyarif al-Makkah al } \\
\text { musyarafah al } \\
\text { munadhomah lilqalam } \\
\text { Malik wakatibuhu } \\
\text { linafsihi Haj Isma'il bin } \\
\text { Muhammad (mim dal } \\
\text { wau) bin Ismail (ta wau } \\
\text { mim dal) (alif ya wau } \\
\text { alif mim) albugis } \\
\text { sesudah 1260 H Amin } \\
\text { Amin ghafarallahu } \\
\text {....pada bulan }\end{array}$ & Kertas Eropa & $\begin{array}{c}\text { Perisai dan } \\
\text { Countermark } \\
\text { G }\end{array}$ & & $\begin{array}{l}\text { Alquran } \\
\text { lengkap }\end{array}$ \\
\hline $\begin{array}{c}\text { Ujung } \\
\text { Pesisi, } \\
\text { Karangasem }\end{array}$ & $\begin{array}{c}\text { Masjid } \\
\text { Baiturrahim }\end{array}$ & Tidak ada & Dluwang & Tidak ada & & $\begin{array}{l}\text { Alquran } \\
\text { lengkap }\end{array}$ \\
\hline $\begin{array}{c}\text { Sindu, } \\
\text { Karangasem }\end{array}$ & $\begin{array}{l}\text { H. Muhsan } \\
\text { dan Bpk } \\
\text { Nuruddin } \\
\end{array}$ & Tidak ada & Dluwang & Tidak ada & & $\begin{array}{l}\text { Alquran } \\
\text { lengkap }\end{array}$ \\
\hline \multirow[t]{4}{*}{$\begin{array}{l}\text { Saren Jawa, } \\
\text { Karangasem }\end{array}$} & \multirow[t]{2}{*}{$\begin{array}{l}\text { Bapak Ayu } \\
\text { Mudin }\end{array}$} & 1. Tidak ada & Kertas Eropa & $\begin{array}{c}\text { Singa } \\
\text { bermahkota }\end{array}$ & & $\begin{array}{l}\text { Alquran } \\
\text { lengkap }\end{array}$ \\
\hline & & 2. Tidak ada & Kertas Eropa & $\begin{array}{c}\text { Singa } \\
\text { bermahkota }\end{array}$ & & $\begin{array}{l}\text { Alquran } \\
\text { lengkap }\end{array}$ \\
\hline & \multirow[t]{2}{*}{ Ibu Murtilah } & 1. Tidak ada & Kertas Eropa & Tidak terlihat & & $\begin{array}{c}\text { Alquran Juz } \\
30\end{array}$ \\
\hline & & 2. Tidak ada & Kertas Eropa & Tidak terlihat & & $\begin{array}{l}\text { Alquran } \\
\text { lengkap }\end{array}$ \\
\hline
\end{tabular}

Salah satu naskah mushaf Alquran di Saren Jawa, yakni milik Bapak Ayu Mudin, ada yang merupakan naskah litografi atau yang sering disebut dengan cetak batu. Meskipun demikian, naskah tersebut menggunakan kertas Eropa. Mengenai cap kertas dan cap bandingan kertas Eropa dalam naskah ini dapat dilihat di keterangan sebelumnya tentang kertas Eropa dan cap kertasnya.

5. Naskah-naskah Berkolofon

Kolofon adalah catatan penutup oleh penyalin naskah dan biasanya terletak di akhir tapi tidak menjadi bagian dari teks itu sendiri. Umumnya, kolofon mengandung informasi tentang identitas penyalin, waktu dan tempat penyalinan, serta informasi lain terkait kegiatan 
penyalinan. Kolofon memiliki peranan penting dalam mengetahui usia dan identitas naskah (Fathurahman, 2010: 96). Namun demikian, dalam tradisi naskah Islam, kolofon tidak harus terletak di akhir teks (Chambert-Loir, 2010: 153). Karena pentingnya kolofon untuk menelusuri sejarah naskah, maka peneliti mencoba mengidentifikasi naskah-naskah keislaman di Klungkung dan Karangasem yang memiliki kolofon. Berikut tabel naskah yang berkolofon.

\section{Tabel 7}

Naskah-naskah Keislaman Berkolofon di Klungkung dan Karangasem

\begin{tabular}{|c|c|c|}
\hline No & Kode & Kolofon \\
\hline 1 & BLAS/SJ/IU/RAM02/2019 & Adapun yang menyurat ini Mikraj....1322 \\
\hline 2 & BLAS/SJ/IU/RAM 06/2019 & $\begin{array}{l}\text { Wa katibuha al-faqir al-haqir al-shagir wasmuha al-haj } \\
\text { Muhammad Arsyad ibn al-marhum Muhammad Halim hina } \\
\text { julus fi Karang Asem fi hijrat al-Nabi SAW sanah } 1310 \mathrm{fi} \\
\text { syahri Dzafr al-Mudzafir hilal } 1 \text { (huruf h) yaum. }\end{array}$ \\
\hline 3 & BLAS/SJ/FIKIH/RAM11/2019 & $\begin{array}{l}\text { Tamat kalam Hari Ahad waktu Duhur Bulan Dzulqa'idah } \\
\text { Tanggal Tiga Puluh Genep }\end{array}$ \\
\hline 4 & BLAS/SJ/TAUHID/RAM36/2019 & $\begin{array}{l}\text { Tamat al-kitab ini pada malam tua waktu Isya bulan Jumadil } \\
\text { Akhir } 1290 \mathrm{H} \text { tahun ini ini kitab diwarisi dari Buitan. Inilah } \\
\text { Kitab Sifat Dua Puluh }\end{array}$ \\
\hline 5 & BLAS/SJ/TASAWUF/RAM63/2019 & $\begin{array}{l}\text { Telah selesai menulis ini kitab pada hari Arba' Jam } 8 \text { Bulan } 12 \\
\text { Dzul Hijjah Tanggal } 17 \text { Tahun Jim }(1351 \mathrm{H}) \text { wa ismuhu alkitab } \\
\text { Asrar al-Insān }\end{array}$ \\
\hline 6 & BLAS/SJ/IU/RAM64/2019 & $\begin{array}{l}\text { 1.Tammat al-kalam bi al-khair wa salam pada bulan Syawwal } \\
\text { tanggal enam belas.....sanah } 1354 \text { pada tahun dal akhir adanya. } \\
\text { 2. Telah khatam pada bulan Syawwal hari Jumat tanggal enam } \\
\text { belas hari enam sanah seribu tiga ratus lima puluh satu tahun } \\
\text { pada tahun dal adanya. }\end{array}$ \\
\hline 7 & BLAS/KCG/AlQURAN/MBR1/2019 & $\begin{array}{l}\text { Khatam nulis Qur'an dina Kamis tanggal sepisan sasi mengaji } \\
\text { tahun ha Hijrah Nabi Saw } 12791800\end{array}$ \\
\hline 8 & $\begin{array}{l}\text { BLAS/DKK/A1QURAN/PDKK1/201 } \\
9\end{array}$ & $\begin{array}{l}\text { Tamat kalimatu rabbika sidqan wa mubadila likalimati fi syahri } \\
\text { dulqa'dah almukaram almubarak fi sanah ba wazalika fil } \\
\text { makan alsyarif al-Makkah al musyarafah al munadhomah } \\
\text { lilqalam Malik wakatibuhu linafsihi Haj Isma'il bin } \\
\text { Muhammad (mim dal wau) bin Ismail (ta wau mim dal) (alif ya } \\
\text { wau alif mim) albugis sesudah } 1260 \text { H Amin Amin } \\
\text { ghafarallahu ....pada bulan }\end{array}$ \\
\hline 9 & BLAS/DKK/IU/PDKK2/2019 & $\begin{array}{l}\text { Tamat alkalam bilkhoiri wassalāmu ajmaīn tersurat kepada } \\
\text {...bulan Dulqa'dah Hari Arba'Tahun } 1312 \mathrm{H}\end{array}$ \\
\hline 10 & BLAS/UP/IU/MBR3/2019 & $\begin{array}{l}\text { Selesai ditulis Isra Mi'raj ini pada } 26 \text { Sya'ban pada } 19 \\
\text { September } 2006\end{array}$ \\
\hline 11 & BLAS/KCG/IU/SMD1/2019 & $\begin{array}{l}\text { Selesai Hari Sabtu tanggal } 07 \text { April } 1990 \text { bertepatan dengan } 12 \\
\text { Ramadhan } 1410 \text { H nama Mahajutin (adiknya Bp Samidin) }\end{array}$ \\
\hline 12 & BLAS/KCG/IU/AM4/2019 & $\begin{array}{l}\text { Wallahu a'lam bissawab tammat kurang lebih dalam tulisan } \\
\text { saya ini maaf kepada yang membaca selesai hari Sabtu tanggal } \\
09 \text { Pebruari } 2002 \text { bulan Dulqa'idah tanggal } 261422 \mathrm{H} \text { yang } \\
\text { menulis Abdul Mahid Kampung Kecicang Islam }\end{array}$ \\
\hline
\end{tabular}

Ada dua belas naskah yang berkolofon. Isi kolofon tidak semuanya lengkap, artinya tidak semuanya mencantumkan nama penyalin atau penulis. Namun, tarikh penyalinan atau penulisan naskah umumnya dicantumkan. Untuk tahun penyalinan, umumnya ditulis tahun hijriah, tetapi ada juga yang ditulis bersamaan dengan tahun masehinya. Beberapa naskah yang hanya dituliskan tahun hijriahnya kami coba hitung konversi ke dalam tahun masehi, yakni sebagai berikut. 
Tabel 8

Konversi Tahun Hijriah ke Tahun Masehi Naskah-Naskah Keislaman di Klungkung dan Karangasem

\begin{tabular}{|l|l|l|l|}
\hline No & Kode Naskah & Tahun Hijriah & $\begin{array}{l}\text { Perkiraan Hasil Konversi } \\
\text { Tahun Masehi }\end{array}$ \\
\hline 1 & BLAS/SJ/IU/RAM02/2019 & $1322 \mathrm{H}$ & 1903 \\
\hline 2 & BLAS/SJ/IU/RAM 06/2019 & $1310 \mathrm{H}$ & 1892 \\
\hline 3 & BLAS/SJ/TAUHID/RAM36/2019 & $1290 \mathrm{H}$ & 1872 \\
\hline 4 & BLAS/SJ/TASAWUF/RAM63/2019 & $1351 \mathrm{H}$ & 1931 \\
\hline 5 & BLAS/SJ/IU/RAM64/2019 & $1354 \mathrm{H}$ & 1934 \\
& & $1351 \mathrm{H}$ & 1931 \\
\hline 6 & BLAS/KCG/AlQURAN/MBR1/2019 & $1279 \mathrm{H}$ & 1862 \\
\hline 7 & BLAS/DKK/AlQURAN/PDKK1/2019 & $1260 \mathrm{H}$ & $1843 / 4$ \\
\hline 8 & BLAS/DKK/IU/PDKK2/2019 & $1312 \mathrm{H}$ & 1894 \\
\hline
\end{tabular}

Adapun naskah-naskah yang disalin abad ke-21, misalnya naskah Hikayat Mikraj dalam kode BLAS/UP/IU/MBR3/2019, BLAS/KCG/IU/AM4/2019, atau yang disalin pada abad ke20, yakni naskah yang berkode BLAS/SJ/IU/RAM02/2019, adalah teks yang cukup lama. Menurut van der Meij (dalam Suryadi, 2015: 372), kolofon naskah Hikayat Isra Mikraj yang dikajinya menunjukkan angka tahun selesai ditulis naskah pada $1782 \mathrm{M}$ (akhir abad ke-18). Dalam penelusuran Meij, kisah Isra Mikraj ini sudah dapat ditemukan sejak abad ke-16, ditulis dalam berbagai bahasa daerah seperti Aceh, Bugis, Jawa, Madura, Makasar dan Sunda, termasuk yang lebih banyak dalam bahasa Melayu. Jadi bisa dikatakan bahwa, meskipun naskah Isra Mikraj yang ditemukan di Karangasem ini berangka tahun sangat muda, namun teks yang disalinnya adalah suatu karya yang tua.

\section{Penutup}

Naskah-naskah keislaman di Bali banyak ditemukan di kampung-kampung Islam. Penelitian ini menemukan 75 naskah-naskah keislaman dari berbagai kampung Islam di Kabupaten Klungkung dan Karangasem. Naskah keislaman terbanyak ditemukan di Kabupatan Karangasem. Kebanyakan naskah berbahan kertas Eropa, lalu kertas dluwang dan kertas bergaris, bahkan ada juga yang lontar. Adapun bahasa yang digunakan kebanyakan menggunakan bahasa Melayu, sedangkan aksara yang digunakan adalah aksara Jawi. Namun ada juga naskah yang menggunakan bahasa-bahasa lain, seperti Jawa, Bali dan Arab. Naskahnaskah keislaman di dua kabupaten tersebut, jika dilihat dari perspektif klasifikasi kepustakaan Islam Kailani, maka kebanyakan naskah-naskah tersebut adalah naskah-naskah dalam klasifikasi Islam Umum, yang terdiri dari teks-teks hikayat, khutbah, dan primbon. Naskahnaskah keislaman di Bali dapat menjadi identitas atau penanda sejarah keberadaan dan corak keislaman di pulau tersebut. 


\section{Daftar Pustaka}

Chambert-Loir, Henri, Oman Fathurahman. (1999). Khazanah Naskah: Panduan Koleksi Naskah-Naskah Sedunia. Jakarta: Ecole française d'Extrême-Orient dan Yayasan Obor Indonesia.

Chambert-Loir, Henri. (2015). Kolofon Melayu. Dalam Muchlis (Ed.). Filologi dan Islam Indonesia. Jakarta: Puslitbang Lektur Keagamaan, Badan Litbang dan Diklat, Kementerian Agama RI.

Fathurahman, Oman. (2010). Kodikologi dan Paleografi. Dalam Muchlis (Ed.). Filologi dan Islam Indonesia. Jakarta: Puslitbang Lektur Keagamaan, Badan Litbang dan Diklat, Kementerian Agama RI. . (2016). Filologi Indonesia: Teori dan Metode. Jakarta: Pranada Media Group dan UIN Jakarta Press.

Jones, Russel. (1974). More Light on Malay Manuscripts. Archipel, 8 (1), 45-58.

Kailani, Muh. (Ed.). (1999). Daftar Tajuk Subyek Islam dan Sistem Klasifikasi Islam Adaptasi dan Perluasan DDS Seksi Islam. Jakarta: Puslitbang Lektur Agama, Badan Penelitian dan Pengembangan, Departemen Agama RI.

Mashad, Dhurorudin. (2014). Muslim Bali: Mencari Kembali Harmoni yang Hilang. Jakarta: Pustaka Al-Kautsar.

Mulyadi, Sri Wulan Rujiati. (1994). Kodikologi Melayu di Indonesia. Jakarta: Lembar sastra UI.

Pigeaud, Theodore G. Th. (1967). Literature of Java: Catalogue Rasionne of Javanese Manuscripts in the University of Leiden and Other Public Collections in the Netherlands (Vol I). Leiden: The Hague, Martinus Nyhoff.

Pudjiastuti, Titik. (2006). Naskah dan Studi Naskah. Bogor: Akademia.

Saefullah, Asep, M. Adib Misbahul Islam. (2009). Beberapa Aspek Kodikologi Naskah Keagamaan Islam di Bali. Jurnal Lektur Keagamaan, 7 (1).

Suryadi. (2015). Isra Mikraj dalam Naskah-Naskah Indonesia. Studia Islamika, 22 (2), 369375.

Zaelani, Anton \& Sudrajat, Enang. (2015). Mushaf Al-Qur'an Kuno di Bali: Jejak Peninnggalan Suku Bugis dan Makassar. Suhuf, 8 (2), 303-324. 


\section{KATA PENUTUP}

Assalamu'alaikum Wr. Wb.

Salam sejahtera untuk kita semua.

Yth. Kepala Pusat Pengembangan dan Pelindungan Bahasa dan Sastra, Badan Bahasa dan Perbukuan Kementerian Pendidikan dan Kebudayaan RI, Prof. Dr. Gufran Ali Ibrahim

Yth. Kepala Pusat Jasa dan Informasi Perpusnas RI, Bapak Teguh Purwanto, S.IP., M.Si.

Yth. Kepala Bidang Layanan Koleksi Khusus Perpusnas RI, Ibu Yeri Nurlita, S.S.

Yth. Para Narasumber Seminar Nasional Naskah yang bertema "Naskah dalam Kajian Antardisiplin pada Era 4.0", yaitu:

1. Prof. Dr. Titik Pudjiastuti

2. Prof. Dr. Oman Fathurahman

3. Dr. Sudibyo

4. Dr. Mu'jizah

Yth. Para Pemakalah seleksi, para peserta, dan para undangan yang berbahagia, yang tidak dapat saya sebutkan satu per satu.

Alhamdulillah, puji syukur ke hadirat Allah swt., kegiatan seminar nasional yang dilaksanakan sejak kemarin pagi, Selasa, 5 November 2019, sampai dengan sore ini, Rabu, 6 November 2019, telah terlaksana dengan lancar. Pertemuan nasional yang secara khusus membahas tentang naskah kuno sudah lama tidak dilakukan di Fakultas Ilmu Pengetahuan Budaya UI. Oleh sebab itu, seminar ini merupakan salah satu tonggak penting, khususnya bagi kami, civitas akademika Fakultas Ilmu Pengetahuan Budaya UI, dalam upaya terus-menerus menghidupkan gairah meneliti naskah serta saling bertukar informasi mengenai apa yang telah dilakukan masing-masing peneliti.

Selama dua hari ini kita dapat menyimak berbagai temuan-temuan penting dari para peneliti naskah yang tersebar dari berbagai daerah di Indonesia, seperti: Palembang, Bengkulu, Jawa Barat, DKI Jakarta, Semarang, dan Yogyakarta. Yang istimewa, hadir pula sebagai pemakalah seleksi, seorang profesor yang datang jauh-jauh dari Inggris, yaitu: Prof. Dr. Andrew Peacock, guru besar di University of St. Andrews. Sebenarnya ada juga beberapa pemakalah seleksi yang berasal dari negeri jiran, Malaysia. Namun, sayang, karena ada kendala, para pemakalah dari Malaysia itu tidak dapat hadir mengikuti kegiatan seminar.

Temuan-temuan penting dan menarik yang disajikan dalam seminar ini merupakan hasil pergulatan para peneliti dengan naskah yang menjadi objek kajiannya di ruang-ruang sunyi perpustakaan atau ruang kerja dan rumah si peneliti. Kadang-kadang hitungan bulan tidak cukup untuk menyelesaikan kajian terhadap naskah; maka tahun pun dilewati oleh peneliti untuk merampungkan pemahamannya terhadap sebuah teks dalam naskah. Oleh sebab itu, seminar nasional ini merupakan salah satu sarana penting untuk mendiseminasikan hasil kajian dan perenungan para peneliti yang telah bersunyi-sepi itu.

Hadirin yang saya muliakan,

Sudah sejak lama muncul kekhawatiran para filolog senior bahwa perhatian dan kajian terhadap naskah makin lama makin memudar, bahkan hilang. Namun, melihat antusiasme para pemakalah dan peserta seminar nasional ini, kekhawatiran itu sirna begitu saja dari diri saya. 
Selama dua hari ini kita dapat menyaksikan tampilnya para pemakalah muda, baik mahasiswa S1, S2, maupun S3, selain para dosen senior dan setengah senior. Selain itu, peserta seminar ini juga tidak dapat dikatakan sedikit, jika pun tidak saya klaim jumlahnya membludak. Oleh sebab itu, kegiatan pertemuan seperti seminar, diskusi, kongres, ataupun simposium, yang khusus membahas naskah dari berbagai perspektif perlu diadakan secara berkala dan berkelanjutan di masa-masa yang akan datang.

Sebelum menutup acara seminar ini, saya harus mengucapkan terima kasih kepada panitia seminar yang dikomandoi oleh Dr. Priscila Fitriasih Limbong, baik dosen maupun mahasiswa, yang telah bekerja keras selama beberapa bulan untuk menyiapkan kegiatan ini. Hasilnya sungguh sangat mengagumkan. Kegiatan seminar dapat dikatakan berhasil; baik dari segi pengorganisasian panitia maupun dari pelaksanaannya. Dalam kesempatan ini saya juga sangat mengapresiasi dua lembaga yang sangat mendukung kegiatan seminar ini, yaitu Perpustakaan Nasional Republik Indonesia dan Pusat Pelindungan dan Pengembangan Bahasa dan Sastra, Badan Pengembangan Bahasa dan Perbukuan, Kementerian Pendidikan dan Kebudayaan RI. Tanpa dukungan dan bantuan finansial dari kedua lembaga ini, niscaya kegiatan seminar nasional ini tidak akan berjalan dengan lancar. Oleh sebab itu, sudah sepantasnya atas nama Laboratorium Filologi Fakultas Ilmu Pengetahuan Budaya UI saya mengucapkan terima kasih yang tak terhingga. Semoga kerja sama dan dukungan terhadap kegiatan pernaskahan terus berlanjut di masa yang akan datang.

Akhir kata, dengan mengucapkan lafal hamdalah, kegiatan Seminar Nasional ini saya nyatakan DITUTUP.

Demikian yang dapat saya sampaikan. Atas perhatian Bapak/Ibu/Sdr. semua, saya mengucapkan banyak terima kasih.

Wa billahi taufik wal hidayah. Wassalamu' alaikum Wr. Wb.

Depok, 6 November 2019

Kepala Laboratorium Filologi

Fakultas Ilmu Pengetahuan Budaya UI,

Dr. Munawar Holil, S.S., M.Hum. 